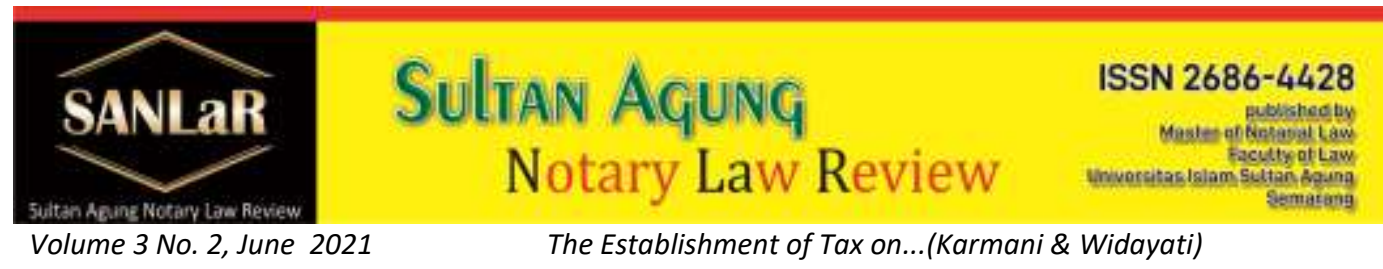

\title{
The Establishment of Tax on Land and Building Rights (BPHTB)
}

\author{
Karmani $^{*}$ and Widayati ${ }^{* *}$ \\ *) Faculty of Law, Universitas Islam Sultan Agung (UNISSULA) Semarang, E-mail: \\ karmaniboyolali@gmail.com \\ $\left.{ }^{* *}\right)$ Faculty of Law, Universitas Islam Sultan Agung (UNISSULA) Semarang, E-mail: \\ widayati@unissula.ac.id
}

\begin{abstract}
This study aims to examine the implementation of the collection of Customs Tax on Land and Building Rights in Boyolali Regency. Reviewing the obstacles that arise in the implementation of the collection of Customs Tax on Land and Building Rights in Boyolali Regency. Reviewing solutions in overcoming the obstacles that arise in the implementation of the collection of Customs Tax on Land and Building Rights in Boyolali Regency. This research is a sociological juridical research. The results of the study concluded that mHowever, there is a discrepancy with the laws and regulations in the implementation of the collection of Duties on the Acquisition of Rights to Land and Buildings in Boyolali Regency, namely when there is a transfer of rights to land and buildings due to a sale and purchase whose transaction value is lower than the market price, the transaction value will be determined by the BPPKAD officer based on market prices and surveys of the tax object in question, even though the provisions of Article 87 paragraph 2 of Act No. 28 of 2009 and Article 7 of Boyolali Regency Regulation Number 2 of 2011 state that the basis for imposing BPHTB taxes on the acquisition of buying and selling rights with lower transaction value rather than the market price, the basis for the imposition of BPHTB tax is the Tax Object Sales Value (NJOP) of Land and Building Tax. In the collection process there are still some obstacles, namely the lack of knowledge of taxpayers regarding information and socialization of the regulations on the Acquisition of Rights on Land and Buildings, as well as the limited number of Human Resources (HR) from the Office of the Regional Financial and Asset Management Revenue Agency of Boyolali Regency, even though the area and number of transfers of land and buildings is small in Boyolali Regency is high, thus interfering with the performance of the Land Deed Maker Officials and the National Land Agency in terms of land registration. There is a need for periodic socialization regarding the Customs for Acquisition of Land and Building Rights by the Regional Government, while the problem of uncertified land requires cooperation with the local National Land Agency, for example conducting a prona program.
\end{abstract}

Keywords: Customs Tax; Land and Building; Rights. 


\section{Introduction}

BPHTB is one of the state tax revenues from taxpayers who make transactions on the transfer of rights to land and / buildings. Acquisition of rights to land and buildings is an act of legal events resulting in the acquisition of rights to land and buildings by individuals or legal entities. Meanwhile, land and building rights are rights to land, including management rights and buildings on it. ${ }^{1}$ In the collection of taxes, one of which is the collection of Duties on the Acquisition of Rights on Land and Buildings, the collection must be transparent to the public, this is solely to improve the tax system, especially the collection of Duties on the Acquisition of Rights on Land and Buildings. The improvement of the system is about justice and legal certainty which is still far from the expectations of the people of Boyolali Regency itself, for example there is verification in the collection of Customs for the Acquisition of Land and Building Rights, which is not regulated in the Boyolali Regency Regional Regulation Number 2 of 2011 concerning Customs. Acquisition of Land and Building Rights. Payment of Duty on the Acquisition of Rights to Land and Buildings is based on the transfer of rights from one party to another. The transfer of rights can occur through buying and selling, inheritance.

In the transfer of rights, the buyer is required to pay the Tax on Transfer of Rights to Land and Buildings in advance of 5\% (five percent) as stated in Article 9 of the Regional Regulation of Boyolali Regency No. 2 of 2011 concerning Customs for Acquisition of Rights to Land and Buildings. The total value of $5 \%$ is the basis of the transaction price or Tax Object Selling Value (NJOP) or Tax Object Acquisition Value (NPOP). After the tax payment is carried out, then the deed is signed in front of the Land Deed Making Officer, because PPAT has the duty as an official for making deeds related to land as stated in Article 3 of Government Regulation Number 37 of 1998 concerning Regulations on the Position of Land Deed Maker Officials.

This is the basis for the withdrawal of duties on the acquisition of land and building rights and income tax from the transfer of rights, the basis of which is the law and nothing else. If there is a difference in the withdrawal of duties on the acquisition of land and building rights as well as income tax, it is certain that an unlawful act that harms the community as a taxpayer itself. The results of the collection of Duties on the Acquisition of Rights on Land and Buildings are managed $100 \%$ (one hundred percent) by the local government of Boyolali Regency as stated in Act No. 28 of 2009 concerning Regional Taxes and Regional Levies, article 95 paragraph (1) which reads as follows: "Taxes are stipulated by Regional Regulation" in conjunction with Act No. 23 of 2014 concerning Regional

${ }^{1}$ Lanny Kusumawati, Hukum Pajak Sebagai Suatau Pengantar, Laros, Sidoarjo, 2005, p. 102. 
Government, that the regions can manage their own regional products independently.

Revenue Service and Regional Financial and Asset Management (DPPKAD)Boyolali Regency is trying to get tax revenue from the process of withdrawing the Customs for the Acquisition of Rights on Land and Buildings because the results from the BPHTB are very large. And the withdrawal made by the regional revenue office is not based on Act No. 20 of 2000, Act No. 28 of 2009 and Boyolali Regency Regulation No. 2 of 2011.

Based on the facts in Boyolali Regency, the withdrawal of Duties on the Acquisition of Rights on Land and Buildings is not in accordance with the Boyolali Regency Regulation Number 2 of 2011. For example, if there is a transfer of rights to land and buildings, the DPPKAD determines that the BPHTB is not in accordance with what is mandated by the Boyolali Regency Regulation which is $5 \%$ of the transaction price or Tax Object Selling Value (NJOP). BPHTB is calculated from the results of field verification (Verlap), Verlap itself is the process of checking directly in the field against objects that are processed from legal actions or legal events. The reason for checking by the DPPKAD is because the Boyolali Regency DPPKAD feels or thinks that the transaction price for the tax object is too low. Even though the PBB SPPT was issued by the DPPKAD itself,

Regarding field verification, it is not regulated either in Act No. 28 of 2009 concerning Regional Taxes and Regional Levies and Boyolali Regency Regulation Number 2 of 2011 concerning Customs for Acquisition of Rights on Land and Buildings. In terms of field verification, the Regional Revenue Service (Dispenda) is not basic or there is no legal certainty in collecting fees for the acquisition of land and building rights. Therefore, the field verification should not be carried out by the Boyolali Regency DPPKAD against the community who will make payments or settle fees for the acquisition of land and building rights. Because this will be detrimental to the wider community, because this field verification is not regulated in the Boyolali Regency laws and regulations.

\section{Research Methods}

This research method uses a sociological juridical approach, data collection using literature study and field research through interviews. The specifications used in this study are descriptive analytical which are intended to provide as accurate data as possible about a condition or other symptom and it is hoped that this research can provide a clear description of the implementation of the collection of Customs Tax on Land and Building Rights in Boyolali Regency. The data analysis method was carried out qualitatively and then presented descriptively. Research problems in analysis with legal certainty theory. 


\section{Results and Discussion}

\subsection{Implementation of Collection of Duties on Acquisition of Land and Building Rights in Boyolali Regency}

Since the enactment of Act No. 21 of 1997 as amended by Act No. 20 of 2000 concerning Customs for the Acquisition of Rights to Land and Buildings (BPHTB) and by adhering to the principles of justice, legal certainty, legality and simplicity, the aim is to expand the scope of tax objects, improve discipline and service to the community as well as the imposition of sanctions for officials and taxpayers who violate the law as well as provide convenience and legal protection to taxpayers in carrying out their obligations, for every acquisition of land and building rights subject to Customs for the Acquisition of Rights on Land and Buildings (BPHTB). The basis for the imposition of BPHTB tax on the acquisition of sale and purchase rights is based on the transaction price.

In accordance with the principle of consensualism that animates the law of the agreement, the agreement was born since the agreement was reached. In a sale and purchase agreement, the agreement of the parties regarding the goods and the price is a condition for the validity of the agreement. Therefore, if the parties (seller and buyer) appear before the PPAT and provide information regarding the goods and prices they have agreed on as objects of sale and purchase, then that information is considered the actual Acquired Value of the Tax Object, and to further strengthen the statements of the parties This can be proven by the existence of a sale and purchase receipt between the seller and the buyer.

Parties other than the parties to the agreement cannot participate in determining the amount of the Acquired Value of the Tax Object. However, if it turns out that the Acquired Value of the Tax Object is below the Sales Value of the Tax Object as stated in the Land and Building Tax Payable Tax Return (SPPTPBB), then the basis for the tax imposition is the Sales Value of the Tax Object. Sales Value of Tax Objects (NJOP) is the average price obtained from sale and purchase transactions that occur fairly, and if there is no sale and purchase transaction, the NJOP is determined through price comparisons with other similar objects, or new acquisition value, or replacement NJOP..

As Article 87 paragraph 2 of Act No. 28 of 2009 and Article 7 of the Regional Regulation of Boyolali Regency Number 2 of 2011 concerning Customs for the Acquisition of Land and Building Rights. What is meant by transaction price is the price that has occurred and has been agreed upon by the parties concerned, while the basis for imposition of BPHTB tax for the acquisition of grant and inheritance rights is based on market value. Market value is the average price of a fair sale and purchase transaction that occurs around the location of the land and or building, which is as stated in the explanation section of article 7 
paragraph (2), namely: (a) Transaction price is the price incurred and agreed upon by the parties concerned. (b) What is meant by market value is the average price of a fair sale and purchase transaction that occurs around the location of the land and/or buildings. In the event of an exchange, both parties are subject to BPHTB".

Article 87 of Act No. 28 of 2009 and Article 7 paragraph 2 of Regional Regulation Number 2 of 2011 states that the Acquired Value of the Sale and Purchase Tax Object is the transaction price and for inheritance and grants is the market value. the seller without having to rely on the market value of the object being traded, as well as showing the amount of money the buyer gave to acquire the land and buildings he bought to the seller's owner as the owner of the land and buildings. The seller and buyer are free to agree on a price that is suitable for both parties, which can be the same, lower or higher than the market price of the object.

Officers of the Regional Financial and Asset Management Revenue and Asset Management Agency of Boyolali Regency (BPPKAD) can find out how much the transaction value in the transfer of sale and purchase rights is by looking at the proof of sale and purchase receipts from the Land Deed Maker Official (PPAT) and the parties. From the sale and purchase receipt, you can find out the amount of NPOP. After the NPOP is known, the BPHTB can be calculated in accordance with Article 10 of the Regional Regulation Number 2 of 2011 which reads: "The principal amount of the BPHTB owed is calculated by multiplying the rate in Article 9 with the basis of tax imposition in Article 7 after deducting the NPOPTKP in Article 8. based on Article 7 paragraph (2) is not known or lower than the Sales Value of the Tax Object (NJOP) used in the imposition of land and building tax in the year the rights are acquired,

Based on the facts in Boyolali Regency, the process of collecting BPHTB has not been fully in accordance with applicable regulations, in particular Act No. 28 of 2009 concerning Regional Taxes and Regional Levies and Boyolali Regency Regional Regulation Number 2 of 2011 concerning Fees for Acquisition of Land and Building Rights, because in some cases of buying and selling transactions where the transaction value is lower than the market price, the transaction value will be determined by the BPPKAD officer based on the market price and a survey or field check of the tax object concerned. ${ }^{2}$ Actually, the process of determining market value requires a certain process and generally cannot be done by everyone, because it requires knowledge and experience of land, buildings, and valuation methods.

Surveys or field checks also require a long time to the detriment of other parties,

\footnotetext{
2 Results of an interview with the Boyolali Regency Land Deed Official (PPAT), dated May 10, 2021.
} 
especially PPAT in making the deed of sale and purchase. The survey or field check is carried out because according to the officer the transaction price proposed by the taxpayer is too low from the market price and the Land Value Zone (ZNT) and to avoid taxpayer fraud, namely manipulating the transaction price so that the BPHTB payment obligation is less.98 The Land Value Zone is an area that describes relatively the same land value from a set of land parcels in it, the boundaries of which are imaginary or real in accordance with the use of the land and have different values between one another based on a comparative analysis of market prices and costs. Regarding surveys or field checks on tax objects, it has not actually been regulated in Act No. 28 of 2009 concerning Regional Taxes and Regional Levies and Boyolali Regency Regulation Number 2 of 2011 concerning Fees for Acquisition of Land and Building Rights, thus making the collection of land rights acquisition fees and buildings in Boyolali Regency there is no legal certainty. This situation is detrimental to the taxpayer, because the actual transaction is not considered and must follow the transaction value calculated by the officer based on the market value, thus the amount of BPHTB that must be paid also increases thus making the collection of fees for the acquisition of land and building rights in Boyolali Regency without legal certainty. This situation is detrimental to the taxpayer, because the actual transaction is not considered and must follow the transaction value calculated by the officer based on the market value, thus the amount of BPHTB that must be paid also increases, so that the collection of fees for the acquisition of land and building rights in Boyolali Regency has no legal certainty. This situation is detrimental to the taxpayer, because the actual transaction is not considered and must follow the transaction value calculated by the officer based on the market value, thus the amount of BPHTB that must be paid also increases.

This is contrary to the tax principle According to Adam Smith (1723-1790) in his book Wealth of Nations, namely the Certainty Principle (certainty), which states that there must be certainty, both for tax officials and all taxpayers and the whole community. The principle of certainty includes, among other things, certainty about who should be taxed, what is the object of tax, and the amount of tax that must be paid and how the amount of tax owed must be paid. This means that certainty is not only related to certainty regarding tax subjects (and their exceptions), tax objects (and their exceptions), tax bases and the amount of tax rates, but also regarding procedures for fulfilling obligations, including payment and reporting procedures, as well as the implementation of tax rights. . Without a clear procedure,

Another method used by officers in determining the amount of tax when the transaction price is lower than the market price, is to follow the price or value determined by the Boyolali Pratama Tax Service Office when paying income tax (PPh) paid by the seller, by asking for proof of payment that has been validated 
by the KPP. Primary. Whereas KPP Pratama has its own pricing basis, which is different from the basis used by BPPKAD. This situation allows for bargaining between taxpayers and BPPKAD officers in determining the transaction value, and is contrary to the theory of legal certainty put forward by John Austin and Van Kan, which assumes that in principle the law is solely to create legal certainty.

The task of the law is to achieve legal certainty for the sake of order and justice in society, because it is certain and fair, the law can carry out its functions. The law must be certain because certain things can be used as a measure of truth and for the achievement of legal goals that demand peace, tranquility and order in society, and legal certainty must be able to guarantee public welfare and guarantee justice for the community.

The collection of fees for the acquisition of land and building rights is principally based on a self-assessment system, namely that the taxpayer is entrusted with calculating and paying the taxes owed by himself using the Regional Tax Payment Letter (SSPD) for the acquisition of land and building rights and reporting without being published. Tax assessments. This self-assessment system is applied to taxes where taxpayers are given the trust to calculate, pay and report the results of the tax calculation itself. There are 5 (five) principles in collecting fees for the acquisition of land and building rights, namely: ${ }^{3}$

a. The Fee for the Acquisition of Rights on Land and Buildings in principle adheres to the system self-assessment is that the taxpayer calculates and pays taxes himself to the tax officer, in the sense that the taxpayer is given full trust from the tax office to calculate, pay and report the tax results. This is a lesson about taxation in which taxpayers can be trusted and can increase public awareness of the importance of taxes for development, especially fees for acquiring land and building rights.

b. Withdrawal or collection of Duties on the Acquisition of Rights on Land and Buildings according to Act No. 28 of 2009 concerning Regional Taxes and Regional Levies, the maximum rate is $5 \%$ (five percent) of the value of the acquisition of taxable objects (NPOPKP). The calculation of the imposition of Customs on Acquisition of Rights on Buildings (NPOP) is the acquisition value of the tax object and first deducted by the acquisition value of the non-taxable tax object (NPOPTKP) which has the same regional rate of IDR 60,000,000.- (sixty million rupiah).

c. In implementing the effective collection of BPHTB, the most important

3 Ulung Probohandoko, Prija Djatmika, dan Titik Soeryati Soekesi, Problematika Yuridis Pemungutan Bea Perolehan Hak Atas Tanah Dan Bangunan Di Kota Malang Di Tinjau Dari Peraturan Daerah Kota Malang Nomor 15 Tahun 2010 Tentang Bea Perolehan Hak Atas Tanah Dan Bangunan, Program Studi Magister Kenotariatan Universitas Brawijaya Malang, p. 12. 
thing is openness and legal certainty. If there are taxpayers and or public officials who violate this provision, they will be subject to the provisions of sanctions applied by the applicable law. This is for the absence of legal deviations between taxpayers and public officials themselves.

d. Payments made by taxpayers for BPHTB in the process of buying and selling land and buildings are state revenues which are fully delegated to the regional government where the regional government coordinates the BPHTB, in the context of regional development as part of regional autonomy.

e. In the BPHTB levy there is a levy that is not in accordance with what is mandated by law, so that what is imposed on the acquisition of land and building rights exceeds the cost calculated according to the law. This may not be done by any party, whether it is a taxpayer or an authorized official on the withdrawal of fees for the acquisition of rights to land and buildings, so as not to become a burden with the collection of fees for the acquisition of rights to land and buildings that do not refer to the law on the acquisition of rights on land and buildings.

\subsection{Barriers to the Implementation of BPHTB Collection in Boyolali Regency}

In the process of collecting BPHTB in Boyolali Regency, there are still several obstacles, namely:

a. Taxpayer's knowledge of information on the Acquisition of Rights on Land and Buildings is lacking.

Taxpayers do not understand the obligation to pay BPHTB making transactions hampered, because before BPHTB is paid in full and must submit proof of BPHTB payment, PPAT cannot make a deed of transfer of rights, this is in accordance with article 91 of Act No. 28 of 2009. The imposition of tariff $5 \%$ of the transaction price is burdensome to the taxpayer because the tariff must be paid before the transfer occurs and in fact it is obligatory not to directly enjoy the proceeds from the sale of the land and buildings.

Based on observations from the community, especially the lay community, they do not know that there is a fulfillment of BPHTB payments in the event of a transfer of land/building rights and the fulfillment of these payments/reports uses the Self Assessment system. As a result, Land Deed Officials (PPAT) in addition to playing a role in assisting Taxpayers to make BPHTB payments in the transfer of land rights but also provide information, explanations, appeals and socialization about the emergence of BPHTB and PPAT also helps deposit the tax at the Regional Government Bank PPAT also plays a role in the submission of monthly routine reports. This report is a monthly report on the deed that has been made by PPAT within one month to be submitted to the Regent, Head of 
the Land Office,

b. Underhand buying and selling, such as the buying and selling process or the distribution of inheritance that has not been subject to a Land and Building Rights Acquisition Fee, namely for lands that have not been certified.

Usually in transactions, it is only confirmed that there are witnesses and knowledge of the Village Apparatus. The transactions they carry out cannot be subject to legal sanctions as regulated in Act No. 16 of 2000 which has been amended by Act No. 28 of 2007 concerning General Provisions and Tax Procedures as well as Act No. 20 of 2000 concerning Amendments to Laws. Act No. 21 of 1997 concerning Customs for Acquisition of Rights on Land and Buildings, because their land has not been certified.

c. Human Resources (HR) from the Office of the Revenue and Financial Management Agency for the Regional Assets of Boyolali Regency are inadequate in number.

At the counter for receiving BPHTB payments, there are only 2 (two) people who specialize in receiving and checking BPHTB payment documents, even though the office serves all transfers of rights to land and buildings in Boyolali Regency whose data has been mentioned above. Seeing this, it is not surprising that the management of BPHTB in Boyolali Regency takes a long time, which results in disruption of the performance of PPAT.

\subsection{Solutions to Overcome Obstacles in the Implementation of BPHTB Collection in Boyolali Regency}

Land and Building Rights Acquisition Fee is a tax related to the registration of land rights. Article 19 of the UUPA states that to ensure legal certainty by the Government, land registration is carried out throughout the territory of the Republic of Indonesia. According to the provisions regulated by Government Regulation. Based on Article 37 paragraph (1) of Government Regulation Number 24 of 1997 concerning Land Registration, any transfer of land rights except through auction can only be registered if the legal act of transferring land rights is based on the PPAT deed. With the enactment of the UUPA.

Such a deed must be made by and in the presence of an official specifically appointed for that purpose, namely the PPAT. At this stage the PPAT's role as a recorder of legal actions to make a deed of sale and purchase must be fulfilled, so that this transfer becomes valid and can be registered behind his name. With this PPAT deed, a new status will be given to the transfer of name application requested by the party receiving the transfer of rights. The making of the deed of 
sale and purchase before the PPAT is carried out for the validity of the agreements relating to land rights, it is required that the deed made by the PPAT is required.

The tax debt arising from the BPHTB taxpayer on the transfer of land rights is when the deed is made and signed before the PPAT. Payments from taxpayers are not based on a Tax Certificate, but arise automatically, because at the time determined by the law, as a consequence, taxes must be paid at the time of the acquisition of rights as referred to in Article 9 paragraph (2) of Act No. 20 of 2000 concerning Fees for Acquisition of Land and Building Rights. This provision is emphasized by the provisions of Article 24 of the BPHTB Law and Article 91 paragraph (1) of Act No. 28 of 2009 which states that a Notary/PPAT can only sign a deed of transfer of Land and or Building Rights after the taxpayer submits proof of tax submission.

This statement is reinforced by Article 6 paragraph (3) of the BPHTB Law which states that if the Acquired Value of the Tax Object is unknown or lower than the Sales Value of the Tax Object used in the imposition of Land and Building Tax in the year the acquisition occurs, except for the appointment of the buyer in the auction, then the tax base used is the Sale Value of Land and Building Tax Objects. The acquisition value of land and building rights is higher than the NJOP means that the State has been harmed by the difference between the acquisition value and the PBB NJOP, but if the acquisition value is lower than the PBB NJOP then the taxpayer or the parties feel that the government is unfair in imposing BPHTB taxes, so the government should stipulate fair regulations, namely setting the PBB NJOP as the exact acquisition value of land and or building rights.

Obstacles faced by taxpayers regarding the BPHTB collection system are the lack of information and socialization regarding BPHTB so that the community's ability to carry out self assessment on BPHTB is not optimal. This problem can actually be corrected by making an annual socialization program which is carried out simultaneously with the submission of the PBB SPPT to the Regional Government, while the problem of uncertified land requires cooperation with the local National Land Agency to carry out prona programs, for example, or counseling carried out together with the Service Office.

\section{Closing}

There is still a discrepancy with the laws and regulations in the implementation of the collection of Duties on the Acquisition of Rights to Land and Buildings in Boyolali Regency, namely when there is a transfer of rights to land and buildings due to a sale and purchase whose transaction value is lower than the market price, the transaction value will be determined by the BPPKAD officer based on market prices and surveys of the tax object in question, even though the 
provisions of Article 87 paragraph 2 of Act No. 28 of 2009 and Article 7 of Boyolali Regency Regulation Number 2 of 2011 state that the basis for imposing BPHTB taxes on the acquisition of buying and selling rights with lower transaction value rather than the market price, the tax base for BPHTB is the Sales Value of Tax Objects (NJOP) of Land and Building Tax. In the collection process there are still some obstacles, namely the lack of knowledge of taxpayers regarding information and socialization of the regulations on the Acquisition of Rights on Land and Buildings, as well as the limited number of Human Resources (HR) from the Office of the Regional Financial and Asset Management Revenue Agency of Boyolali Regency, even though the area and number of transfers of land and buildings is small. In Boyolali Regency is high, thus interfering with the performance of the Land Deed Maker Officials and the National Land Agency in terms of land registration. There is a need for periodic socialization regarding the Customs for Acquisition of Land and Building Rights by the Regional Government, while the problem of uncertified land requires cooperation with the local National Land Agency, for example conducting a prona program.

\section{References}

Books:

[1] Adrian Sutedi, 2006, Peralihan Hak Atas Tanah dan Pendaftarannya, Sinar Grafika, Jakarta.

[2] Adrian Sutedi, 2013, Hukum Pajak. Jakarta: Sinar Grafika.

[3] AP. Parlindungan, 1988. Pendaftaran Tanah Tanah dan Konfersi hak milik atas tanah menurut UUPA, Alumni, Bandung.

[4] Atep Adnya Berata, 2003, Bea Perolehan Hak Atas Tanah Dan Bangunan Menghitung Objek dan Cara Pengajuan Keberatan Pajak, PT. Elex Media Komputindo, Jakarta.

[5] B.llyas dan Richard Burton, 2013. Hukum Pajak (Teori Analisis Dan Perkembangannya), Edisi 6, Jakarta: Salemba Empat.

[6] Bachtiar Effendie, 1993, Pendaftaran Tanah Di Indonesia Dan Peraturan Pelaksanaannya, Alumni, Bandung.

[7] Boedi Abdullah, 2011. Pengantar Hukum Keluarga, CV Pustaka Setia, Bandung.

[8] Bohari, 2001. Pengantar Hukum Pajak. RajaGrafindo Persada. Makassar. 
[9] Budi Harsono, 2003. Hukum Agraria Indonesia, Djambatan, Jakarta.

[10] Carl Joachim Friedrich, 2004. Filsafat Hukum Perspektif Historis, Bandung, Nuansa dan Nusamedia.

[11] Departemen Pendidikan dan Kebudayaan, 2011, Kamus Besar Bahasa Indonesia, Balai Pustaka, Jakarta.

[12] Edy Ruchyat, 1999, Politik Pertanahan Nasional Sampai orde Reformasi, Alumni, Bandung.

[13] Effendi Perangin, 1994, Hukum Agraria Di Indonesia, PT. Raja Grafindo Persada, Jakarta.

[14] Erly Suandy, 2005, Hukum Pajak Edisi Ketiga. Jakarta: Salemba Empat.

[15] Hasan Wargakusumah, 1995. Hukum Agraria I, PT. Gramedia Pustaka Utama, Jakarta.

[16] Irene Eka Sihombing, 2005, Segi-segi Hukum Tanah Nasional dalam Pengadaan Tanah untuk Pembangunan, Jakarta: Universitas Trisakti.

[17] John Rawls, A Theory of Justice, London: Oxford University Press, 1973, Terjemahan oleh Uzair Fauzan dan Heru Prasetyo, 2006. Teori Keadilan, Yogyakarta, Pustaka Pelajar.

[18] Kartini Muljadi,dkk., 2004. Hak-Hak Atas Tanah. Prenada Media, Jakarta.

[19] L..J. Van Apeldoorn, 1996. Pengantar Ilmu Hukum, Jakarta, Pradnya Paramita, cetakan kedua puluh enam.

[20] Lanny Kusumawati, 2005. Hukum Pajak Sebagai Suatau Pengantar, Laros, Sidoarjo.

[21] Madjid Khadduri, 1999, Teologi Keadilan (Perspektf Islam), Risalah Gusti, Surabaya.

[22] Mardiasmo, 2016, Perpajakan Edisi Revisi Tahun 2016. Yogyakarta: Penerbit Andi. 
[23] Marihot P. Siahaan, 2010, Hukum Pajak Elementer. Yogyakarta: Graha Ilmu.

[24] Marihot Pahala Siahaan, 2010, Kompilasi Peraturan di Bidang BPHTB, Graha Ilmu, Yogyakarta.

[25] Marihot Pahalamana Siahaan, 2006. Bea Perolehan Hak Atas Tanah Dan Bangunan Teori DanPraktek, Edisi 1 ,Cetakan 1, Jakarta: PT. RajaGrafindo Persada.

[26] Mujiyati, 2008, Perpajakan (Buku 1). Cetakan Pertama, Muhammadiyah University Press, Surakarta.

[27] Mukti Fajar, Yulianto Achmad, 2015, Dualisme Penelitian HukumNormatif dan Empiris, Yogyakarta, Pustaka Pelajar.

[28] Murtadha Muthahhari, 1995, Keadilan Ilahi: Azas Pandangan Dunia Islam, Mizan, Bandung.

[29] R.Santoso Brotodiharjo, Pengantar Ilmu Hukum Pajak, edisi 4, cetakan 1, Bandung: Rafika Aditama.

[30] Ronny Haniatjo Soemitro, 1990. Metode Penelitian Hukum dan Jurumetri, Jakarta: PT Ghalia Indonesia.

[31] Siti Resmi, 2014, Perpajakan Teori dan Kasus Edisi 8. Jakarta: Salemba Empat.

[32] Sudikno Mertokusumo, 2005. Mengenal Hukum Suatu Pengantar. Yogyakarta: Liberty.

[33] Sudirman Rismawati dan Amiruddin Antong, 2012, Perpajakan Pendekatan Teori dan Praktik. Malang: Empat Dua Media.

[34] Sukrisno Agus dan Erlita Trisnawati, 2014, Akuntansi Perpajakan. Edisi 3. Jakarta: Salemba Empat.

[35] Supramono dan Theresia Woro Damayanti, 2010. Perpajakan Indonesia (Mekanisme dan Perhitungan), Yogyakarta : Andi Offset.

[36] Urip Santosa, 2010. Pendaftaran dan Perolehan Hak Atas Tanah. Kencana, Jakarta. 
[37] Y. Sri Pudyatmoko, 2009, Pengantar Hukum Pajak. Edisi Revisi. Yogyakarta: Andi Offset.

Journals:

[1] Fanny Dewi Sukmawati, Abdul Rachman Budiono, dan Nurdin, 2015. Pembayaran Pajak Penghasilan Dan Bea Perolehan Hak Atas Tanah Dan Bangunan Dalam Pengalihan Hak Atas Tanah Dan Bangunan, Program Studi Magister Kenotariatan, Universitas Brawijaya, Malang.

[2] Pan Mohamad Faiz, 2009. Teori Keadilan John Rawls, dalam Jurnal Konstitusi, Volue 6 Nomor 1 April 2009.

[3] Tarjo dan Kusumawati, 2010, Analisis Perilaku Wajib Pajak Orang Pribadi Terhadap Pelaksanaan Self Assessment System Studi di Bangkalan. JAAI Vol. 10 No. 1. Tahun 2010.

[4] Ulung Probohandoko, Prija Djatmika, dan Titik Soeryati Soekesi, 2017. Problematika Yuridis Pemungutan Bea Perolehan Hak Atas Tanah Dan Bangunan Di Kota Malang Di Tinjau Dari Peraturan Daerah Kota Malang Nomor 15 Tahun 2010 Tentang Bea Perolehan Hak Atas Tanah Dan Bangunan, Program Studi Magister Kenotariatan Universitas Brawijaya Malang.

Regulations:

[1] Act No. 28 of 2009 concerning Regional Taxes and Regional Levies.

[2] Act No. 23 of 2014 concerning Regional Government.

[3] Government Regulation Number 27 of 1996 concerning Payment of Income Tax on Income from the Transfer of Land and Building Rights.

[4] Regional Regulation of Boyolali Regency Number 2 of 2011 concerning Customs for Acquisition of Rights on Land and Buildings. 